\title{
The Teaching and Propagation Methods of the sacred Life, Character and Conduct of the holy prophet in the Quranic context
}

\author{
"Dr. Hafiz Muhammad Sani \\ ". Dr. Nosheen Zaheer
}

Amanullah

\section{ABSTRACT:}

The main and silent features of Prophet Muhammad (SAW) distinctive Prophet hood are his teachings and Propagation of the religion of Islam to the humanity. Allah sent him as the last of this Prophets. The teachings and invitations of religion as imparted and extended to human kind are the eternal arguments showing that the message given by the Prophet (SAW) is the last, and his Prophecies are eternal establishing the religion Islam as the eternal rule for mankind from the Creator. This research undertakes the Principles and methods of preaching and propagation adopted by the Prophet. They are studied and researched scientifically, analytically and logically in the context of the Holy Quran and the life, character and conduct of the Prophet. The research brings out the witnesses that the principles and method practically applied by the Prophet for teaching, preaching and propagation Islam as the eternal religion provide eternal source of guidance, betterment and solution for human beings irrespective of any sort of differences. So, they are the principles and methods which can be applied successfully for preaching and propagating Islam, as the only religion meant for human kind throughout the world.

Keywords: Holy Quran, Preaching of Islam, Methodology, Contemporary Era. The first and the for most base and origin of the disposition and model of the Holy life, conduct and character of the leader of Prophets, head of the apostles, lord of the Universe Muhammad (SAW) is the open book, the glorious, the distinguished book, the magnificent Quran, and this is the only Book for the authenticity superiority and basic for the books to be written on the life and disposition of Prophet. It is truly called the fountain head of the holy life and conduct of Prophet. This Book frequently mentions the topics, subjects and discussion of the holy life. So, the exegists of all times have narrated these aspects with complete explana-tions and commentaries. A detail analytical view of the Quran presents many different events and conditions of the life and conduct of the Prophet detail or in short. The magnificent Quran mentions quite frequently the battles in which the Prophet took part himself, the most important events, the salient features of the Prophet his distinctions and miracles. In this way, the individual and distinguished aspects of the holy life of Prophet come up promine-

*PhD Scholar, Department of Islamic Studies, Faculty of Islamic Sciences, Federal Urdu University, Abdul Haq Campus, Karachi. Email: amanamin400@gmail.com

"Head, Department of the Quran and The Holy Traditions, faculty of Isalmic Sciences, Federal Urdu University, Abdul Haq Campus, Karachi.

"*"Dean, Faculty of Humanities, SBK Women University, Quetta 
ntly through the Quran. It, rather, becomes, clear that both the Quran and the Prophet are inevitable to each other. ${ }^{1}$ However, it is a fact that in the books of history and on his life and conduct put forward the holy life, events and related incidents with a point of view of history and biography. But when the same events are mentioned in the Quran they are mentioned with the teaching and propagation point of view. Since the Quran is not the book of history or a biography. It is rather, infact, a book of invitation and commemoration. So, this Philosophy is very much evident from every verse of the Quran. The Quran presents the events in such a way and style that they become source of benefits up to the dooms-day to all human beings. It infers and deduces such results and out comes which serve the guiding force and the light house for the benefits of all and invites attention towards the realities that can be eye openers. One example of such events is "The Event of I'faq." The style of the Quran is both terse and comprehensive. So, the Quran narrates only those events of the life of Prophet which are deemed necessary, and these aspects are described which carry advice and lessons. But the books on the life of the Prophet narrate the events and the aspects in details. For example, the event of Flight and Ascension of the Prophets mentioned in brief in the Quran, whereas the details of it are narrated in the books on the life of Prophet and in the collections of the Traditions ${ }^{2}$. One noticeable difference is of the method and style of narration. The Quran is the highest master piece of literature of events. The zeal, enthusiasm of narration, simplicity, spontaneity, humor latitude of Psychology, grandeur and eloquence found in the verses of the Quran are match less and unprecedented. The Quran takes over the senses of the readers of it and it is its miracle and uniqueness. No book obviously can claim such a distinction. There got to be great difference in between the books of the Creator and the creatures.

The glorious Quran is the greatest fountain head of the magnificent practice of the Prophet who is the greatest creation. The wife of the Prophet, the mother of the believers, Aayesha daughter of Siddiq narrates that one day a person questioned her about the character of the Prophet. She replied .............. ${ }^{3}$

Another Tradition relates her saying.................... ${ }^{4}$

No one can have better character than the Prophet. His character was the Quran. If the Quran is happy with someone, the Prophet is happy with him, as well. One who makes the Quran angry, that person makes the prophet angry too. The Prophet was not a vulgar speaker, nor he was one to make noise in the markets. Neither he treated in devilish actions devilish way, rather he was fond of ignoring and excusing the evildoers. The mother of the believers, Ayesha Siddiq relates a Tradition which explains this reality in full that the holy life and grandeur conduct of the Prophet is completely mentioned in the Quran. So, the Quran has the primary importance in regard of the source and teachings of the Prophet which are mentioned as the basic sources by the historians and the biographers of the life of Prophet. The enthralling reflections can be seen in the mirror of the Queen of the Prophet, one of them is that establishes him the Prophet of the highest status Prophet. The Prophet of such stature whose advent was prophesied in the divine books and scriptures. So according to the 
Quranic verses the Prophet is the reward of the Prayers of the friend of Allah, Abraham, and the glad tidings of the Messiah -Jesus. His name is Muhammad, and Ahmed, too. In the word of Allah he is called Yasin, the leaders of human beings, Taha, Muzzail the wrapped one, Mudasir the engulfed, the Prophet who is divinely literate, the preacher from Allah, Munzar the revealed, the brightening sun, the pure, the teacher of the book and wisdom, the true apostle, the proof of the Sustainer, the undisputed ruler, complete guide, mercy for mankind, the most merciful, the kind, the holder of the best character, the first Muslim, the seal of the Prophet hood, the servant of Allah, the holder of Kausar the holder of the high status and grandeur, the center of desire of the behaviors, beloved of God and praised by the angles. None the less, the highest characteristic of the Prophet according to the Quran is that the Prophet is the servant of Allah and His Prophet. This proves that the Prophet, as a person, has the status of such a man who is bestowed and given the assignment of Prophet-hood, the preacher of religion and teacher of religion ${ }^{5}$. The reflections of Prophets life in Macca and Medina and the narration of his life in there, beginning of the revelation, preaching of Islam in Macca, opposition of the Quresh and the tortures they inflicted on him, embracing of Islam by pure souls, the difficulties in the way of preaching Islam, the event of Ascension, the migration of the oppressed Muslims to Abysinia, all are clearly seen in the Quran. The orphanage of Prophet his brought up in poverty, economical well being in the youth, the pure life before being assigned Prophethood, planning of the infidels to kill Prophet, migration to Madina, with Abu Bakar Siddiq, taking refuge in the cave Soor, the characters and conduct of Muhajireen, Ansars, immigrants and the helpers, the hypocrates, and the Jews of the Madina and Prophet's treatment and dealings with them, people of the plate form Suffah, destruction of the mosque Zarrar, building of the mosque of Qubah, control of the Quibla, Battles of Badr, Uhad, Hunain, Tabouk, Treaty of Hudaibiya, the Allegiance Oath of Ridhvan, the victory of Macca, the last sermon, etc are mentioned in such details that the collection of the related verses can give the complete life history the biography of the messenger of Allah. All these events are mentioned, some in details, and some in brief.

\section{The verses of the Quran and the status of the holder of the Quran:}

It is absolutely correct to say that the Quran is the basic source and fountain head of life, character and conduct, teachings, guidance and the exemplary behavior of the Prophet. The Quran contains the basic knowledge and information on the status, position, guidance teachings and life of Prophet. It gives the basic help in writing and editing the life of Prophet. The biographers of the life of Prophet have taken complete support and benefits from the basic source, the Quran, in writing and editing the life history of Prophet. The following verses give us the interesting glimpses of life of Prophet. They also give us the basic knowledge on the Prophet-hood of him and its distinction his Sharia position, guidance and advice, teachings, the seal of Prophethood, completion of religion, his status among the messengers of Allah, love of messenger, obedience of messenger, him being greatest creation, as preacher, teacher, his propagation of religion, styles and methods, his matchless character, etc., So, in every 
period of time the exegists have rendered great services and written and compiled great works of writing and editing the life of Prophet in the light of the Quran. They have discussed the related topics and subject matters in the light of the Quran for the biography writing of Prophet. They have done great work on the life and discussion on the life of Prophet. Here, it is meant to present the analysis on the life of Prophet in short specifically on the fields of preaching, teaching and style of Prophets Life and the obligatory duties of the assignment of Prophethood as preacher and teacher in the light of Quran. It is necessary, at the first step, in regard of writing the biography of Prophet what was the objective of the apostleship of the messenger of Allah? What were the universal objectives of Allah for which the messenger of Allah was selected? The questions have been answered in details in the Quran in this way: "Verily, Allah has conferred a favor on the believers by raising among them a messenger from among themselves, who recites to them His signs, and purifying them and teaches them the Book and wisdom; and before him, they were surely in manifest error "6.

Here, in this verse the Quran has explained the basic points of the life of the messenger of Allah which is the objective of the Prophethood and is the important aspect of the life of Prophet. It explains that the Quran is not only the primary and basic source of the life but it also discusses the objective of the life. It also guides to make the studies of the life of Prophet purposeful and pay attention to the aims of the life of Prophet. It is not the objective only to know the events but academic lesson should be learnt from it and also it should be applied in practical life.

\section{The messenger of Allah: as the Teacher and Preacher:}

The Quran has not only given emphasis on the magnificent merits of messenger of Allah, the glorious life of the messenger and on their discussion, but puts emphasis on the completion of religion, assignment of the seal of apostleship and Prophet-hood, giving much more emphasis on the aspects of teaching ad preaching of the life of the messenger of Allah. So hints are given towards the preaching events of the Prophet and complete guidance in his teachings and preaching and the method implied for them. In this way, different aspects of the life of Prophet are brought into the Quranic light and guidance. Quran says while warning on this aspect of the life of Prophet. "O Messenger convey to the people what has been revealed to you from your Lord, and if you do it not, you have not conveyed His message at all"7

Quran has also given this explanation in regard of other apostles that they had fully managed to call their peoples towards Allah, and they did not leave any stone unturned in this regard. The Quran says about the apostle hood that he had sent to his people. "I deliver to you the message of my Lord and I am to you a sincere and faithful

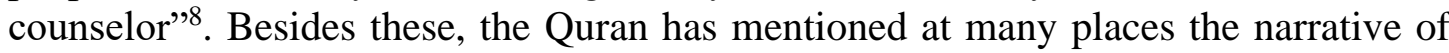
the performance, the obligation of preaching and teaching in general and particularly in regard of the prophet. It has also mentioned the difficulties and hardship which were faced in the way of performing the obligations of this duty. The Quran has mentioned the quality of the Prophet with particular emphasis which has shown as being the preacher, teacher in propagating the apostleship from Allah. It is mentioned 
in different ways and in different references and contexts. It is said by Allah in the chapter Al-Saff: "He is, who has sent his Messenger with the guidance and the religion of truth, He may cause it to prevail over all religions"9

This is the mission of the apostle of Allah, and this is the reason that the status and position of apostle which is more prominent over all other of his qualities of him being the preacher of the truth from Allah. The messenger of Allah at one incident was addressed in the Quran in this way: "And we have not sent you but as a bearer of glad tidings and a Warner"10. The messenger of Allah was ordered to announce this by addressing all human kind: "Say, O mankind! truly I am a messenger to you all from Allah"11. Moreover, the whole universe is encircled by the preaching and teachings of the Prophet. The Quran says, in this reference. "Blessed is He who has sent down the discrimination to his servant, that he may be a Warner to all the worlds. He to whom belongs the kingdom of the heavens and the earth. ${ }^{12}$

\section{Mode of preaching and teaching of the messenger in the light of Quran:}

Whereas, the Quran has explained the topic that the most important position and the distinguish status of the messenger of Allah is being the teacher and preacher of the truth, it has also explained the basics of the style and methods of teaching and preaching, all has covered all the aspects of the life of messenger in this regard. It includes to be kind and soft in performing the duties of the obligations of preaching and to have such strategy for teaching, to deal the opponents with wisdom and intelligence and calling eloquently and effectively the addressees towards Islam. These are the best methods of preaching which can be applied in every period of the human history and in the contemporary time period for the preaching and teaching of religion to make this act of performance more effective and powerful. Some important aspects of the methods and styles of the Prophet in regard of preaching and teaching in the light of the Quran and presented here:

\section{1: to Observe and Apply Wisdom and Vision:}

The Quranic method of narration is to keep under consideration the preaching, the vision, wisdom and the highest reason in the teachings of Allah. The messenger of Allah applied this style throughout his life. Allah says in the Quran: "Say, this is my way, I call to Allah on sure knowledge" 13 . This Quranic verse explains the method of the prophetic preaching, which is based primary on the wisdom. Wisdom is an exhaustive word. It has different and various explanations. However, they are not opposite to each other, rather, they support the comprehensiveness of this word. The exegist Ibne Jareer Tabri, writes while explaining it that people should be called towards Allah with full belief and knowledge ${ }^{14}$. Allama Nasfi says: "Wisdom means that the opponents should be called to the teachings of religion with vivid and unambiguous arguments." 15 . Imam Raghib Isphani writes while explaining the word: Wisdom is called the heart power which is full of intelligence and belief. ${ }^{16}$

The conclusion is that it is the prophetic method to preach and teach religion with full confidence, belief, wisdom and knowingly applying them in accordance with requirement of the situation. It is obvious from the study of the Quran that it is implied in the 
method and style of preaching be continued disregarding the opponents. Allah says: "And let them not turn you away from the signs of Allah, after they have been sent down to you; and call human kind to your Lord. ${ }^{17}$. In the present time, the preacher's lack of knowledge and belief have rendered less effective the practice of preaching and even the needs of wisdom and vision are not, generally, fully applied.

\section{2: Sincerity, Selflessness and Ferment:}

The Quran vividly presents this reality in regard of the teachings and preaching of religion by the messenger of Allah that this practice of him needs, sincerity, sympathy and ferment on top of other righteous deeds. Because no one is ready to accept the invitation of the preacher unless he has firm belief in the sincerity, selflessness and passions of the preacher. There should be only one desire and fervor in style and method of argumentation of the preacher of the truth, and it is his passions, sympathy and selflessness towards the addressee. This aspect is the prominent point in the practice of preaching by all apostles of Allah. There is one desire and enthusiasm in their argumentations, the passionate appeal and narration of exemplary events to attract the addressee to listen the voice of truth and accept the truth of it. The sacred people are not only in cognition of this reality by them-selves but also make the listeners to realize, through different reasons, their self-lessness sacrifice because the recognition of it benefits the preaching of religion. Every messenger of Allah, and particularly the leader of the messengers and the seal of the messengers made his addresses realize that he does not have some self benefit and gains through this preaching of religion. The Quran has often quoted this sentence of them with reference to the messengers of Allah: "And I ask of you no reward for it ${ }^{18}$. "My reward is only with the Lord of the worlds" 19 ."My rewards are not due except from Him who created me. Will you not then understand?"20

The famous researcher of the Islamic World Dr. Yousuf al Qardhani writes:

"People who are giving the invitation of the teachings of Allah should always keep this concept in their vision vividly clear that they are performing their duties in regard of Islam. And, then, on the second level, they should seek the reward of this deed in the hereafter. The need of this struggle and strive to have worldly gains through them should be kept at the third level. If the work of preaching Allah's teachings is undertaken with this point of view, it means that the obligations are observed and duties performed. And if this noble deed is performed with the conditions, necessary for the action, with sincerity, selflessness and passions, there is no doubt that there will be reward of it from Allah in the hereafter and the possible worldly gains as the result of this pious action. However, when and what kind of benefit will result out of this action is the decision of Allah. Sometimes, at any moment and any level such great and blessed results appear which cannot be anticipated" 21 .

In the present time, it is necessary to have sincerity and, selfless-ness to be blended together and passions, sympathy and kindness should be applied in presenting the brightened advice and commands of Islam to attract the non Muslims towards Islam. In this way the preaching and teachings of Islam will be much more effective to them. 
There seems to be no reason of not being effective if the preaching of Books is fully filled and with sincerity with the spirit of sympathy.

\section{3: Abstinence of force and coercion:}

The principles the Quran have been mentioned for the application of preaching and teaching. An important principle out them is not to apply force and coercion for just is trusting one's argue and not to compel any one to accept other point view. There should not be any sort of duress at the first stage of preaching any way. However, after the establishment of the truth force may come into considera-tion. But the Quran has negated all these doubts. The Quran says: "There should be no compulsion in religion. Surely right has become distinct from wrong; so whosoever refuses to be led by those who transgress, and believes in Allah, has surely grasped a strong handle which knows no breaking. And Allah is all hearing, all knowing ${ }^{22}$. Famous Arab Scholar Dr. Jamaluddin Atia writes in "Popular Concept of the Sharia of Islam": A human being, in the guidance of the direction of Allah and His revelation can find out the human values through one's intelligence and wisdom. He can strive to get right and justice for building of life and society and can put into practice one's planning with the help of one's determination. It is indispensable after accepting this that human freedom and liberty should also be accepted which is the basic philosophy of the system of Islam. According to this concept of the Islamic Sharia a human being is free and independent from all sorts of physical and collective coercion. So, there is no provision of any kind of physical and collective coercion under the Islamic system." 23 Imam Shafi has presented the most beautiful interpretation of the laws of difficulties and accountability. He says: "The objective of the sharia is to get human being free from the worship of one's self and put the one in the service of the Sustainer. So, it is necessary that one has authority on ones' actions as one is the servant and obedient to Allah in ones restless and creative life" ${ }^{24}$. The conclusion is that there is no concept of compulsion and coercion force and duress in the style and method the Quran that has been narrated for the preaching of religion. Rather, attraction of the addressee towards religion should be made due to wisdom, vision and kindness.

\section{4: Consideration of Time and Place:}

It is mandatory to have real and true zeal and devotion for religious preaching and without them it can not be accomplished. However, it is very much detrimental if no consideration is given to time and place due to the zeal and enthusiasm. So, a religious preacher should avoid preaching on all these times when the addressee is simply resorted to objections and criticism. Not only this, but the religious preacher should not extend the discussion even when after presenting religious preaching the addressee is bent up on to opposition and criticism. It is better for the religious preacher to leave the scene and go away from the place in that sort of situation, and keep waiting for an other suitable chance where the addressee is devoid of at least opposition and critical thoughts and trend. Allah says: "And when you see those who engage in vain discourse concerning Our signs, then turn you away from them until they engage in a discourse other than that. And if Satan causes you to forget, then, sit not, after recollection, with 
the unjust people" 25 . It is very much necessary to take into consideration the time place and the situation for preaching religious teachings in the light of the directions of the Quran, and sayings and teachings of the messenger of Allah. And this is the style and method that plays primary rule in having power and effect for Preaching.

\section{5: Observing Endurance, Tolerance and Amicable way of Discourse:}

One basic rule to observe as suggested by the Quran with reference to the style and method of religious preaching by the preacher is softness and well being in discourse. It creates good effect and impact on the mind of the addressee and he/she feels himself/ herself intended to accept the preaching. Whereas, harshness and force in style of preaching create hatred and enmity feelings in the others mind. Due to such feelings the other person shows stubbornness and obstinacy in ones being wrong and on mistake. This attitude renders the preaching fruitless. So, the Quran has advised Prophets to talk softly even with bitter enemies. Moses and Aaron are advised to go to the Pharaoh who was so adamant for preaching the message of the Lord, and with this advice of Allah they are commanded to: "Go both of you, to Pharaoh, for he has transgressed all bounds". "But speak to him a gentle speech that he might possibly heed or fear" 26 . "To deal someone in a better way, to have soft voice talk, show kindness, pleasant, tolerant, endurant, all are included in the meaning"27. Hafiz Ibn-e-Hajr Aasqalani put the meaning of softness in a comprehensive way: "It is to show softness in speech and action, and adopt easy aspect in every matter, and it is opposite to harshness." 28

\section{6: Magnificent Advice: The effective style of the Prophetic Teaching:}

Good advice is a basic thing for religious preaching. It means to give a good advice. A good advice has two basic things: One is that the addressee should not be limited to be convinced only on reliance of argumentations, but he/she should feel an appeal in his heart for the arguments. Sins and wrongs should not only be refuted on the basic of logic, rather, on the inborn hatred for them which is embedded in the nature of human beings for them should be invoked, and fear of their worse results should also be created. Secondly advice should be given in such a way that sincerity and passions are very well be felt. The addressee should not have the feelings that the preacher is thinking him inferior to the advisor, and he is enjoying his superiority. The addressee should feel that the advisor honestly means his reformation and he is worried about him. The addressee, hence, feels that he advisor in real, wants his betterment ${ }^{29}$. "Religious teachings and preaching is not a mechanical commotion that it is suffice to give some arguments, repeat few words and feel content that the duty and obligation is performed. Religious preaching needs intensive devotion, passions and sincerity." 30 In the Quran, wherever, order of preaching and propagating religion is given, different words are used there in this regard which advice and warn to have good advice, wisdom and better style. At one occasion Allah says: "Call into the way of your Lord with wisdom and goodly exhortation, and argue with them in a way that is best" 31 . Imam Ibn Qarni writes with this reference: "This verse emphasis this thing that the followers of the Prophet are the people of wisdom, and they call towards Allah in preaching based on wisdom. And one who is not among them, then, despite of claim to 
follow the prophet in real one is not amongst the obedients of the messenger of Allah." 32 .

\section{7: Honesty, Sincerity and Selflessness in the Prophetic Teaching:}

It is necessary that the preacher should be free of enemy sort of gain and self interest for the effectiveness of Preaching of truth. The only purpose of the preacher should be to proclaim the word of Allah and Propagation of the religion of Islam. The Quran has repeatedly said that the messenger of Allah does not have any attachment of his own objective with the preaching of the teachings of Allah. The preaching only consumes his heart and soul in this work of preaching the truth for the betterment of human kind the creature of Allah. Allah says: "So follow you their guidance. Say: I ask not of you any reward for it. This is nothing but an admonition for all mankind"33. The life, character and conduct of the messenger of Allah in this regard, are clear examples and models. The Prophet invited people toward Allah without having any consideration of his own gains and benefits, and in result people entered in the fold of Islam in multitude numbers one after the other. The invitation of Islam over came an effectively all other preferences.

\section{8: Platience, Firmness and Solidarity Practice:}

The invitation of the Prophet with reference of the Quran clearly shows the patience, firmness and solidarity very prominently. The messenger held patience throughout this life. He endured all and different sorts of troubles and difficulties in the way of preaching the truth. He remained firm dispite of all and different kinds of opposition and prejudices. And he kept on inviting people to Allah is message in all and in very much odds and untoward conditions. He remained the embodiment and paragon of this order of Allah: "To this, then, do you invite mankind. And be your stead, fast as you are commanded" 34 . This is the reason that Quran says while commanding to be firm: "So stand you upright, as you have been commanded" 35

\section{9: Amicable Character and Meritorious Conduct Exposition:}

The first obligation of Prophet is preaching and teaching. It means that whatever the message of Allah has been revealed to him, he must let the people to hear it, whatever, reality he is made cognizant by Allah, he must let Prophet be aware of it, invest all his energy and power in this way Lead the people to the right path with every effect of truth, not only to undertake every difficulty and trouble in the proclamation and invitation but to take all that as comfort and understand all of them in this regard. Beat peace and take the thorns piercing in his feet in this way as flowers. Whatever hinders his way and becomes of an obstacle stone in his way remove he must it and undertake all these efforts with sole objective of pleasure of Allah, and consider it in regard of betterment of mankind. All this is nothing but the accomplishment of the obligation of Prophethood and nothing else. Today, in this world, love of God, love of brotherhood, love of humanity, help of the destitute, assistance of the poor, and all other virtues and their existence on the earth are due to the invitation and preaching efforts and endeavors of the messenger of Allah. This all their effect and impact. The great thinkers and philosophers' poets and sagas believe that to understand themselves or to let the other understand is their obligation. But the apostles, whatever truth they find, put their full and best efforts to make it to be 
understood others, and they strive in every possible way to Propagate and convince on it all the world. They make unwise people to understand with enduring every difficulty in this regard, and lead the blinds on the right path ${ }^{36}$. The Quran mentions and narrates the best conduct and amicable manners of the messenger of Allah in these words: "you are kind towards them, and if you had been rough and hard hearted, they would surely have dispersed from around you" 37

It was the enthralling and miraculous attraction which was pulling people towards him like a magnate to enter into the fold of Islam and used to dispel the ignorant and illiterate doubts and suspicion of the pagans within no time.

\section{List of the Discussion:}

The Quran, like all other sciences, is the basic source of the science of Prophet's biography which brings up different aspects of the life, conduct and character of the Prophet quite prominently. However, the Quran does not present stories and events as objectives, it, rather, narrates the events with the consideration of description, sermon and advice. So, the same aspect is also explained prominently. The points and aspects open up through the Quran, in regard of the life of Prophet, also give the methods and styles of the Prophet on invitation, preaching and teaching. All these aspects are narrated briefly in this article. They include interest way of advising, sincerity, honesty, character and conduct, hospitality and humbleness, difficulties and troubles endured in the way of truth, show of patience and determination on being in trouble some situation. In the present time the effectiveness of religious invitation is lessening day by day. The basic reason of that lack is distance from the prophetic method, style and qualities. If the style of the Prophetic method of invitation is tried for preaching and propagating the message of Islam, it will surely bear fruit and will be effective and gainful.

\section{Directions and Suggestions:}

1: $\quad$ There is a need of ponderation and deep thinking on the Quranic verses, so that new vistas of knowledge can open up and pleasant change may occur in academic and practical life.

2: $\quad$ It is the most needed thing, that the Prophetic qualities and merits should be created in regard of the preaching of religion, otherwise, the practice of preaching religions will be rendered soulless and the required results would not be achieved.

3: $\quad$ The guiding directions that the Quran has given in regard of the invitation of truth should be adopted to make it possible to perform this obligation much effectively, so the positive change can be brought in the society.

4: $\quad$ The people who are engaged in invitation and preaching activities should come into this field keeping the preaching aspects of the life, conduct and character of the Prophet practically and act upon and practice, all those qualities and characteristisc of the character and conduct which are mentioned by the Quran as the guiding force. 5: As, every Muslim has the status of a preacher of the religion of the messenger of Allah and is the representative of the religion of Islam, so he/she must build his/her individual and collective life on the patterns of the life of Prophet. So that there should be peace and tranquility in his/her life and it becomes a source of guidance for others. 


\section{Source and Base:}

${ }^{1}$ Asjad Qasmi, Moulana, Seerat Nabvi: Life of the Messenger of Allah, Quran Majeed Kay Aainey Mein, in the light of the Quran, Karachi, Al-Nabras, 2002, p09

${ }^{2}$ Ibid

${ }^{3}$ Behrul Fawaid Al Musani Bamani Al Akhbar, Abu Bakar Muhammad Bin Ibi Ishaq Al Kalabazi, Al Bukhari, Al-Hanafi, Dar-ul-Kitab al Allam a Beirut, Vol of 1420 A/1, p336

${ }^{4}$ Salahi, Muhammad Bin Yousuf, Subul Huda Wal Rashad, (Cairo, Egypt, 16/2)

${ }^{5}$ Anwar Mahmood Khalid, Dr. Urdu Nasr (Prose), Main Seerat-e-Rasool Biography of the Messenger of Allah in Urdu Prose Iqbal Academy, Lahore, Pb. 1989, P. 47

${ }^{6}$ Al-Quran: 03,164

${ }^{7}$ Al-Quran:05,67

${ }^{8}$ Al-Quran: 07,158

${ }^{9}$ Al-Quran:09,33 ...61,33

${ }^{10}$ Al-Quran:34,78

${ }^{11}$ Al-Quran:07,68

${ }^{12} \mathrm{Al}-Q u r a n: 25,01$

${ }^{13}$ Al-Quran:12,08

${ }^{14}$ Al-Tabri, Muhammad Bin Jareer, Abu Jafar, Jamaa-al-Bayan, Mosasa at Rasai Vol. of 1420, 291/16

${ }^{15}$ Al-Nasfi, Abdullah Bin Ahmed, Hafizuddin, Madarik Tanzeel, Dar-al-Kalm, Beirut, 1419 AH, 138/2

${ }^{16}$ Al-Raghib of Isphani, Al-Hasain Bin Muhammad, Muradaat-al-Quran, Dar-al-Ilm, 1412, P.127

${ }^{17}$ Al-Quran:78,87

${ }^{18}$ Al-Quran: 26,109

${ }^{19}$ Al-Quran: 26,145

${ }^{20}$ Al-Quran:11,51

${ }^{21}$ Mahanama (Monthly)Turjuman-al-Quran (Interpreter of the Quran) Lahore, July, 2004, pp13-20

${ }^{22}$ Al-Quran: 02,256

${ }^{23}$ Jamaluddin Atia, Dr. Shariat-e-Islami ka Aamoomi Tasawwar, Translator Maulana Habib ul Haq, Islamabad, Sharia Academy, 2004, p29

${ }^{24}$ Shatbi, Mowafqat, Beirut, 168/2

${ }^{25}$ Al-Quran:06,68

${ }^{26}$ Al-Quran:20,43-44

${ }^{27}$ Ferozuddin, Moulvi, Feroz-al-Lughat, Lahore, Feroz sons, p356

${ }^{28}$ Ibne Hajar, Ahmed Bin Ali, Fateh al Bari, Darul Maarfa, Beirut, 1379, 449/10

${ }^{29}$ Khalid Alvi, Dr. Rasool-e-Akram Ka Minhaj-e-Dawat, p65

${ }^{30}$ Ibid

${ }^{31}$ Al-Quran: 16,125

${ }^{32}$ Al-Jasas, Ehkaam-al-Quran, Beirut, 179/3, Al-Shokani, Muhammad Bin Ali, FathulQadeer-Al Jaajma Bani Fini, Al-Rawayah-wal-Darayah Min, Al-Ilm, Al-Tafseer, Macca-al-Mukarama al Tijarsh: 84/2

${ }^{33}$ Al-Quran:06,90

${ }^{34}$ Al-Quran:42,15

${ }^{35}$ Al-Quran: 11,112

${ }^{36}$ Syed Suleman: Nadvi, Seerat-al-Nabi, Al-Faisal Nasheran, Lahore, 67/4

${ }^{37}$ Al-Quran: 03,159

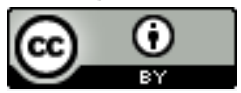

This work is licensed under a Creative Commons Attribution 4.0 International License. 